\title{
Use of radiocarbon from nuclear fallout as a dated marker in the otoliths of haddock Melanogrammus aeglefinus
}

\author{
Steven E. Campana* \\ Marine Fish Division, Bedford Institute of Oceanography, PO Box 1006, Dartmouth, Nova Scotia, Canada B2Y 4A2
}

\begin{abstract}
Radiocarbon $\left({ }^{14} \mathrm{C}\right)$ activity in the world's oceans roughly doubled between 1950 and 1970 as a result of the atmospheric testing of nuclear weapons. Through comparison with the ${ }^{14} \mathrm{C}$ time series reconstructed from nearby corals, Kalish (1993) used the ${ }^{14} \mathrm{C}$ activity of fish otolith cores as a means of confirming the annulus-based age estimates for those fish. Here I report the first pre-and post-bomb ${ }^{14} \mathrm{C}$ chronology based only on young fish otoliths, thus avoiding all assumptions concerning the age and date of uptake into the otolith, and any requirement for reference coral chronologies. On the basis of accelerator mass spectrometry (AMS) assays, the ${ }^{14} \mathrm{C}$ activity of 103 young haddock Melanogrammus aeglefinus otoliths collected of the eastern coast of Canada increased sharply between 1958 and 1965 and remained elevated thereafter, in phase with published ${ }^{14} \mathrm{C}$ chronologies for bivalves and corals in the North Atlantic. Assays of the ${ }^{14} \mathrm{C}$ content of the extracted otolith core of old haddock served as a dated marker of the year of hatch, thus providing an absolute age determination for individual fish which was accurate to within 1 to 2 yr. Internationally accepted criteria for annulus interpretation in haddock otoliths appear to be accurate to an age of at least $10 \mathrm{ys}$, and to within 2 to $3 \mathrm{yr}$ for haddock up to an age of $22 \mathrm{yr}$

KEY WORDS: Otolith A Age determination Bomb radiocarbon Fallout V Validation Melanogrammus aeglefinus
\end{abstract}

\section{INTRODUCTION}

In a seminal paper, Kalish (1993) described the use of radioactive fallout as a dated marker in fish otoliths, and its value for confirming age interpretations. The paper was based on earlier work which had documented the rapid increase in atmospheric fallout products as a result of the widespread testing of atomic bombs in the 1950s and 1960s (Nydal \& Lovseth 1983). These fallout products were subsequently incorporated into the world's oceans in a manner which has been well described at large spatial scales (Broecker et al. 1985, Duffy et al. 1995). Through analysis of annual growth rings in coral, later researchers demonstrated that at least 1 of the fallout products, radiocarbon $\left({ }^{14} \mathrm{C}\right.$ or carbon-14), was incorporated into the accreting coralline structure in concentrations proportional to

·E-mail: s_campana@bionet.bio.dfo.ca those present in the water column (Druffel 1989). Thus the time series of bomb radiocarbon in the coral was shown to reflect that present in the marine environment, which roughly doubled between 1950 and 1970 . Using accelerator mass spectrometry (AMS) as a sensitive and accurate assay tool, Kalish (1993) was able to demonstrate that the otoliths of a New Zealand fish species also incorporated ${ }^{14} \mathrm{C}$, and that the time series of radiocarbon reconstructed from the presumed otolith annuli was similar to that present in nearby corals. Thus he was able to infer that the otolith annuli had been interpreted and aged correctly, since systematic under-or over-ageing would have resulted in a phase shift between the otolith ${ }^{14} \mathrm{C}$ and the coral ${ }^{14} \mathrm{C}$ time series.

Despite the global acceptance of otolith annuli as the best means for estimating the age of most fish species, the correct interpretation of the annuli is far from trivial, and can result in serious and systematic ageing error (Beamish \& McFarlane 1995, Campana 1995). 
Indeed, aside from the use of tagged, hatchery-reared fish released into the wild, confirming the accuracy of a method of annulus interpretation for marine fish species is generally problematic. Mark-recapture of chemically tagged individuals is currently the most accurate means of confirming the frequency of formation of presumed annuli, through comparison of time at liberty with the number of annuli deposited distal to the chemical check (Foreman 1996). Unfortunately, extremely low recapture rates for fish at liberty more than 2 to 3 yr can compromise the generality of the technique; uncertainty in the identification of even a single annulus constitutes an unacceptably high proportion of the total post-mark period in fish at liberty $<3$ yr. Alternatively, radiochemical dating based on ${ }^{210} \mathrm{~Pb}:{ }^{226} \mathrm{Ra}$ or ${ }^{228} \mathrm{Th}:{ }^{228} \mathrm{Ra}$ ratios can be used to differentiate between very different age interpretations (Bennett et al. 1982, Campana et al. 1990), but these assays are too imprecise for detailed or individual age confirmations. The most widely used approach, that of the seasonal progression of marginal increments (Beckman \& Wilson 1995), is well suited only to fastgrowing fish, and suffers from the lack of an objective means of evaluation. Thus there is a well defined gap in our ability to confirm the age interpretations of the majority of marine fish species. In contrast, the dated mark left in fish otoliths by nuclear fallout is theoretically capable of providing an accurate and absolute age for individual fish.

Kalish (1995a, b) has continued to apply the bomb radiocarbon technique to problems of age validation in several other fish species. Similarly, researchers in other disciplines have used bomb radiocarbon assays to infer age and the frequency of growth ring formation in bivalves (Turekian et al. 1982. Peck \& Brey 1996) and mammals (Bada et al. 1990). Yet the approach has not yet gained general acceptance among fisheries biologists, in large part because of the presumed necessity of assuming temporal coherence between the ${ }^{14} \mathrm{C}$ uptake chronology of the otolith and the nearest available reference coral (which can be thousands of km away).

Here I report the first pre-and post-bomb ${ }^{14} \mathrm{C}$ otolith chronology based only on young fish, thus avoiding all assumptions concerning the age and date of ${ }^{14} \mathrm{C}$ uptake into the otolith, and any requirement for reference coral chronologies. I then use this ${ }^{14} \mathrm{C}$ 'reference curve' to determine the absolute age of a sample of old fish, through interpretation of ${ }^{14} \mathrm{C}$ assays of the extracted otolith cores. Finally, I compare otolith annulus counts with the ${ }^{14} \mathrm{C}$-derived ages from the same fish, thereby confirming the relative accuracy of internationally accepted ageing criteria for haddock Melanogrammus aeglefinus of the eastern coast of Canada.

\section{MATERIALS AND METHODS}

All otolith samples were drawn from archived research vessel and commercial otolith collections of haddock from southeastern Newfoundland off the eastern coast of Canada (NAFO Division 30) held at the Northwest Atlantic Fisheries Centre in St. John's, Newfoundland. Additional samples were also drawn from a neighbouring stock to the west (NAFO Division 3Ps) in order to test for geographic and/or stock variation. All otoliths had been stored dry in paper envelopes prior to examination and analysis.

The ${ }^{14} \mathrm{C}$ reference curve was developed using 103 randomly selected young haddock collected between 1952 and 1985 whose age, based both on otolith examination and fish length, was 1 to $3 \mathrm{yr}$. The majority of the fish $(66 \%)$ were 1 yr old (mean length $\pm \mathrm{SD}=$ $20.4 \pm 4.1 \mathrm{~cm})$, while $19 \%$ were 2 yr old $(30.2 \pm 2.5 \mathrm{~cm})$ and $15 \%$ were 3 yr old $(32.2 \pm 1.3 \mathrm{~cm})$. Modal fish lengths at such young ages are generally diagnostic, and any inaccuracy in the age estimation of these fish is unlikely to exceed $1 \mathrm{yr}$. Random samples $(n=20)$ of large, presumably old haddock were drawn both from the 3Ps and the 30 collections, with emphasis on fish believed to have hatched in the $1960 \mathrm{~s}$. The mean length of these fish was $80.0 \pm 4.5 \mathrm{~cm}$.

All otoliths were thoroughly cleansed of adhering tissue and potential contaminants using a soft-bristled brush and Super $Q$ water, followed by sonification. All but a small subsample were then embedded in polyester resin (Strong et al. 1985) and sectioned transversely through the core, as well as on either side of the core. Thus 3 thin sections, each approximately $1 \mathrm{~mm}$ thick, were available from each otolith.

In principle, the decontaminated $1 \mathrm{yr}$ old otoliths could have been submitted intact for ${ }^{14} \mathrm{C}$ assay. However, to insure consistency in the way that the young and old otoliths were prepared, otolith cores corresponding to the first year's growth were removed from all samples. In order to test for any contamination effects from the embedding and coring procedure on the ${ }^{14} \mathrm{C}$ assay, a subsample of 9 otoliths from a single 1971 collection of age 1 fish was prepared and analyzed in a paired comparison of otolith cores versus intact otoliths. Coring was carried out using a lasersighted otolith coring device developed at the Bedford Institute of Oceanography, in which a hollow diamondcoated drill bit with an inside diameter of $1.5 \mathrm{~mm}$ was used to extract the centre of each otolith from each transverse section. Since the diameter of the first annulus in transverse sections of Scotian Shelf haddock otoliths is approximately $3.0 \times 1.4 \mathrm{~mm}$ (Campana 1995), extracted cores were probably a reasonable approximation of the first year's growth. The laser sighting device provided good alignment of the drill bit 
with the otolith core, but minor misalignments undoubtedly occurred. Note that any such misalignments would have resulted in sampling of more recently deposited material.

All samples were weighed and wrapped in aluminum foil in preparation for AMS assay of ${ }^{14} \mathrm{C}$. Since the core extraction procedure described above sometimes generated less than the $10 \mathrm{mg}$ required for assay, some otolith samples were pooled with other samples of identical age. All samples were also individually assayed for $\delta^{13} \mathrm{C}$, which was used to correct for isotopic fractionation effects. Radiocarbon values are hereafter reported as $\Delta^{14} \mathrm{C}$, which is the per mil $(\%)$ deviation of the sample from the activity of 19 th-century wood, corrected for isotopic fractionation (relative to the PDB standard) and sample decay prior to 1950 , according to methods outlined by Stuiver \& Polach (1977)

To determine the annulus-based age for each of the adult haddock, the remaining otolith from each pair was embedded and sectioned in preparation for viewing with an image analysis system. Unfortunately, many of these otoliths had been previously broken, resulting in sections which were lateral to the core. Although the resulting age estimates are probably comparable to those which would have resulted from a properly centred transverse section, it is possible that the first annulus was missed in some otoliths, resulting in an age underestimate of 0 to 1 yr. In retrospect, annulus counts should have been made from the same thin sections that were later cored for ${ }^{14} \mathrm{C}$ assay.

\section{RESULTS}

The assay results for $\delta^{13} \mathrm{C}$ showed relatively little variation across the range of samples (mean $\pm \mathrm{SD}=$ $-1.45 \pm 0.68$ ), despite a slight but significant increase across years $\left(b=0.044, p<0.01, r^{2}=0.30\right.$ ) (Table 1 ). In contrast, $\Delta{ }^{14} \mathrm{C}$ differed strongly and systematically though time, ranging from -73 in the late 1940 s to +69 in the period after 1970. There was no significant difference in $\Delta^{14} \mathrm{C}$ between the 3Ps and 30 collections $(p>$ 0.4 ), and no significant difference between cored and intact otoliths of the same age and yearclass $(p>0.7)$. Thus there was no evidence of geographic variation over the spatial scale of sampling, and no evidence of $\Delta^{14} \mathrm{C}$ contamination from the otolith coring procedure. Otolith cores from the 1963 yearclass at age 1 were significantly lower in $\Delta^{14} \mathrm{C}$ than were the cores from the same yearclass at age $2(p<0.05, n=6)$, suggesting that the coring process might have incorporated some otolith material deposited after the first year of life. However, the rate of increase in $\Delta^{14} \mathrm{C}$ during the mid 1960 s was so rapid that the apparent age effect might simply be an artifact of the season of collection.

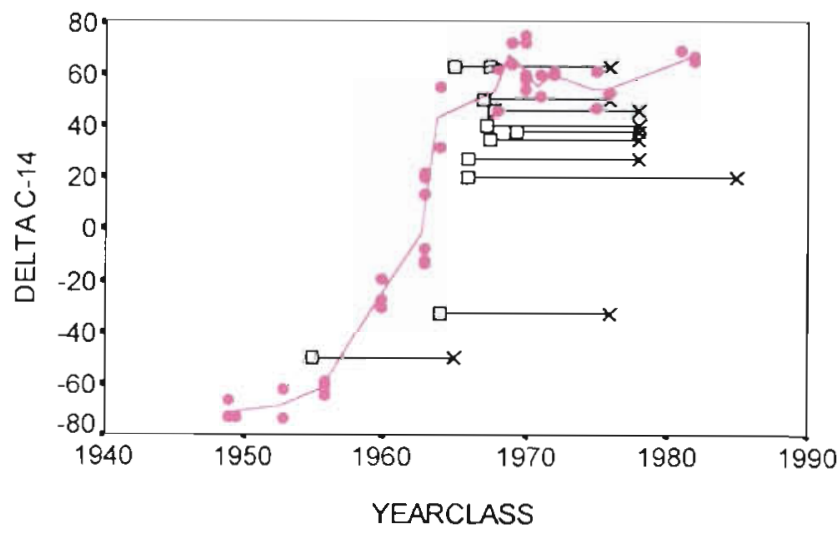

Fig. $1 \quad \Delta^{14} \mathrm{C}$ incorporated during the first year of growth of young haddock otoliths (O) increased so rapidly during the period 1958 to 1965 that it could be used as a yearclass-specific marker Through comparison with this reference curve $\Delta^{14} \mathrm{C}$ concentrations in adult otolith cores were used to determine the yearclass of adult haddock. A horizontal line has been drawn connecting the year of collection of each adult fish $(\mathbf{X})$ with its estimated yearclass ( $\square$ ) based on annulus counts. Thus the length of the line indicates the annulusbased age of the fish, while the length of a horizontal line connecting the year of collection to the reference curve indicates the $\Delta^{14} \mathrm{C}$-based age. The reference curve values have been fitted with a LOWESS curve

The amount of $\Delta^{14} \mathrm{C}$ in the core of young haddock otoliths was relatively low and constant prior to the late 1950s, increasing sharply to a new asymptote after 1970 (Fig. 1). The maximum rate of increase occurred between 1958 and 1965. There was no evidence of the expected decline in $\Delta^{14} \mathrm{C}$ after 1970 , nor were there sufficient samples prior to 1950 to detect the Suess effect (Weidman \& Jones 1993). Within-year variation was small compared to the increase between 1958 and 1965 , to the extent that 1 to 2 yr periods could be differentiated statistically from the adjacent time period. Therefore, the amount of $\Delta^{14} \mathrm{C}$ in the young haddock otoliths was characteristic of the year of incorporation, and could reasonably be considered a dated marker.

Radiocarbon assays of the otolith core from adult haddock implied ages that were much lower than indicated by the year of collection on the reference curve, as would be expected (Fig. 1). Indeed, since the year of formation of the otolith core corresponds to the yearclass of the fish, the $\Delta^{14} \mathrm{C}$ of the otolith core from the adult haddock should be the same as the $\Delta^{14} \mathrm{C}$ value of the same yearclass at age 1 on the reference curve. Thus the interval between the year of collection and the corresponding $\Delta{ }^{14} \mathrm{C}$ value on the reference curve indicates the $\Delta^{14} \mathrm{C}$-based age of the fish. These ages varied between 8 and $22 \mathrm{yr}$, with an uncertainty of 1 to $2 \mathrm{yr}$. Also indicated on Fig. 1 are the annulus-based ages of the fish which, allowing for the uncertainty in the tra- 
Table 1. Summary of ${ }^{14} \mathrm{C}$ and $d^{13} \mathrm{C}$ assay results for each otolith sample. Young haddock (ages 1 to 3 yr were used to develop the reference curve, while the cores of old fish were used as test samples. $n$ = number of otoliths pooled to make up the sample

\begin{tabular}{|c|c|c|c|c|c|c|}
\hline $\begin{array}{l}\text { Sample } \\
\text { classification }\end{array}$ & Yearclass & $\begin{array}{l}\text { Year of } \\
\text { collection }\end{array}$ & $\mathrm{n}$ & $\begin{array}{l}\text { Annulus } \\
\text { age }\end{array}$ & $\begin{array}{c}{ }^{14} \mathrm{C} \\
(\text { mean } \pm \mathrm{SD})\end{array}$ & $d^{13} \mathrm{C}$ \\
\hline \multicolumn{7}{|l|}{ Reference } \\
\hline & 1949 & 1952 & 2 & 3.0 & $-71.8 \pm 7.0$ & -2.4 \\
\hline & 1949 & 1952 & 2 & 3.0 & $-65.8 \pm 5.0$ & -2.9 \\
\hline & 1950 & 1952 & 2 & 2.5 & $-71.8 \pm 7.0$ & -3.6 \\
\hline & 1953 & 1954 & 4 & 1.0 & $-72.8 \pm 7.0$ & -2.0 \\
\hline & 1953 & 1954 & 3 & 1.0 & $-61.8 \pm 6.0$ & -1.5 \\
\hline & 1956 & 1959 & 2 & 3.0 & $-60.8 \pm 7.0$ & -1.3 \\
\hline & 1956 & 1959 & 3 & 3.0 & $-59.8 \pm 5.0$ & -1.9 \\
\hline & 1956 & 1959 & 3 & 3.0 & $-58.8 \pm 6.0$ & -2.1 \\
\hline & 1956 & 1959 & 2 & 3.0 & $-63.8 \pm 7.0$ & -2.0 \\
\hline & 1960 & 1961 & 3 & 1.0 & $-19.6 \pm 7.0$ & -1.0 \\
\hline & 1960 & 1961 & 2 & 1.0 & $-27.6 \pm 6.0$ & -1.2 \\
\hline & 1960 & 1961 & 2 & 1.0 & $-30.6 \pm 6.0$ & -1.2 \\
\hline & 1963 & 1964 & 3 & 1.0 & $-7.5 \pm 6.0$ & -0.9 \\
\hline & 1963 & 1964 & 3 & 1.0 & $-13.5 \pm 7.0$ & -1.4 \\
\hline & 1963 & 1964 & 3 & 1.0 & $-12.5 \pm 6.0$ & -1.5 \\
\hline & 1963 & 1965 & 3 & 2.0 & $13.6 \pm 6.0$ & -1.0 \\
\hline & 1963 & 1965 & 3 & 2.0 & $19.7 \pm 6.0$ & -1.0 \\
\hline & 1963 & 1965 & 3 & 2.0 & $21.7 \pm 7.0$ & -0.6 \\
\hline & 1964 & 1965 & 2 & 1.0 & $31.7 \pm 7.0$ & -1.7 \\
\hline & 1964 & 1965 & 2 & 1.0 & $54.9 \pm 7.0$ & -1.0 \\
\hline & 1968 & 1969 & 2 & 1.0 & $61.9 \pm 7.0$ & -0.4 \\
\hline & 1968 & 1969 & 2 & 1.0 & $45.8 \pm 7.0$ & -1.3 \\
\hline & 1969 & 1970 & 3 & 1.0 & $72.0 \pm 6.0$ & -2.3 \\
\hline & 1969 & 1970 & 3 & 1.0 & $63.9 \pm 6.0$ & -1.4 \\
\hline & 1970 & 1.971 & 1 & 1.0 & $75.0 \pm 7.0$ & -1.1 \\
\hline & 1970 & 1971 & 1. & 1.0 & $53.9 \pm 7.0$ & -1.6 \\
\hline & 1970 & 1971 & 1 & 1.0 & $57.9 \pm 6.0$ & -1.5 \\
\hline & 1970 & 1971 & 3 & 1.0 & $72.0 \pm 6.0$ & -1.3 \\
\hline & 1970 & 1971 & 3 & 1.0 & $59.9 \pm 7.0$ & -1.5 \\
\hline & 1971 & 1973 & 2 & 2.0 & $51.8 \pm 9.0$ & -1.8 \\
\hline & 1971 & 1973 & 2 & 2.0 & $59.9 \pm 7.0$ & -2.5 \\
\hline & 1972 & 1973 & 3 & 1.0 & $60.9 \pm 7.0$ & -1.3 \\
\hline & 1972 & 1973 & 5 & 1.0 & $59.9 \pm 7.0$ & -1.3 \\
\hline & 1975 & 1977 & 1 & 2.0 & $60.9 \pm 7.0$ & -0.4 \\
\hline & 1975 & 1977 & 2 & 2.0 & $46.8 \pm 8.0$ & -0.5 \\
\hline & 1976 & 1977 & 5 & 1.0 & $52.8 \pm 7.0$ & -1.5 \\
\hline & 1981 & 1983 & 2 & 2.0 & $68.9 \pm 7.0$ & -1.2 \\
\hline & 1982 & 1983 & 3 & 1.0 & $66.9 \pm 8.0$ & -0.4 \\
\hline & 1982 & 1983 & 4 & 1.0 & $64.9 \pm 6.0$ & -0.9 \\
\hline \multicolumn{7}{|l|}{ Test } \\
\hline & 1955 & 1965 & 2 & 10.0 & $-49.7 \pm 7.0$ & -2.0 \\
\hline & 1964 & 1976 & 3 & 12.0 & $-32.6 \pm 7.0$ & -2.1 \\
\hline & 1965 & 1976 & 2 & 11.0 & $62.9 \pm 7.0$ & -2.0 \\
\hline & 1966 & 1978 & 2 & 12.0 & $26.7 \pm 7.0$ & -1.4 \\
\hline & 1966 & 1985 & 1 & 19.0 & $19.7 \pm 7.0$ & \\
\hline & 1967 & 1976 & 1 & 9.0 & $49.8 \pm 7.0$ & -1.3 \\
\hline & 1967 & 1978 & 2 & 10.8 & $39.8 \pm 7.0$ & -2.6 \\
\hline & 1968 & 1976 & 1 & 8.5 & $62.9 \pm 7.0$ & -2.2 \\
\hline & 1968 & 1978 & 2 & 10.5 & $34.7 \pm 7.0$ & -1.5 \\
\hline & 1968 & 1978 & 2 & 10.3 & $45.8 \pm 5.0$ & -1.5 \\
\hline & 1969 & 1978 & 2 & 8.8 & $37.8 \pm 6.0$ & -1.1 \\
\hline
\end{tabular}

jectory of the reference curve, give a reasonable approximation to the ${ }^{14} \mathrm{C}$-based age. There was no significant difference between the 2 forms of age determination up to and including age 10 ; annulus counts tended to underestimate the ${ }^{14} \mathrm{C}$-based age by up to 2 to 3 yr for fish between 14 and 22 yr of age

The number of annuli visible across the otolith radius differed with the transect selected for ageing. 
In all otoliths examined as part of this study, annulus clarity, spacing and consistency with the $\Delta^{14} \mathrm{C}$-based age were optimized in the thickened region (proximal-ventral surface) immediately adjacent to the sulcus (Fig 2). Annuli were generally interpretable along the core-dorsal axis (larger of the 2 lobes found each side of the core) as well, but only to an age of about 8 to 10 yr Annuli were not found consistently along the core-distal axis beyond an age of 5 to $7 \mathrm{yr}$, despite the fact that this axis was often the secondlongest in the section. Thus, annuli were apparent along most axes in fish up to an age of 5 to 7 yr. However, the most complete sequence of annuli in older fish was only evident in the axis extending from the core to the thickened proximal-ventral region immediately adjacent to the sulcus.

\section{DISCUSSION}

Kalish's $\left(1993,1995 \mathrm{a}\right.$, b) interpretation of the ${ }^{14} \mathrm{C}$ time series reconstructed from otolith cores of $\mathrm{New}$ Zealand fish resulted in strong inferences about the ages of those fish; any errors in his annulus-based age determinations should have become apparent in a mismatch between the coral ${ }^{14} \mathrm{C}$ time series and that reconstructed from the otoliths. Of course, the underlying assumption of such a comparison is that the youngof-the-year fish incorporated ${ }^{14} \mathrm{C}$ into their otoliths over the same time period as that of nearby corals. The results presented here demonstrate that such an assumption is unnecessary when the appropriate otolith material exists. By using only young fish (essentially of known age) from the study area, one avoids all assumptions concerning the age and date of uptake, and all assumptions concerning parallelism between the incorporation rates of corals and fishes. Given the inert nature of the fish otolith (Campana \& Neilson 1985), the ${ }^{14} \mathrm{C}$ activity in the young fish otoliths provides a reliable and unambiguous calibration curve against which the core activities of older fish can be compared. In the case of haddock, the ${ }^{14} \mathrm{C}$ activities incorporated between the years 1958 and 1965 were so specific to those years that they could be considered dated markers of the year of incorporation.

It is difficult to conceive of a mechanism through which the ${ }^{14} \mathrm{C}$-based ages reported here could be interpreted as other than a minimum age. In principle, if the older haddock originated from a different area or stock than those used to develop the reference curve, geographic variability in the rate of incorporation could be invoked. However, it is unlikely that the haddock under study could have originated elsewhere (Zwanenburg et al. 1992), and in any event, there was no evidence of geographic variability in ${ }^{14} \mathrm{C}$ activity between the 2 adjacent stock areas. Indeed, the period of increasing ${ }^{14} \mathrm{C}$ activity appears to be the same among all organisms yet studied in the North Atlantic, whether derived of fish, coral or bivalve tissue (Fig. 3). A more likely source of error is associated with the extraction of the otolith core, during which contamination with material of more recent origin (e.g. outer annuli) may have occurred. While care was taken to minimize any such contamination, it is important to note that any such error could only result in elevated ${ }^{14} \mathrm{C}$ levels, and hence a younger inferred age. Artificially depleted ${ }^{14} \mathrm{C}$ activities would not have been possible, since no part of the otolith was formed before the year of hatch. Thus the ${ }^{14} \mathrm{C}$-based age of the fish is actually a minimum age; contamination could artifactually reduce the age estimate, but it could never increase it. In practice this is fortunate, since virtually all controversial age interpretations reflect possible age underestimation rather than overestimation (Secor et al. 1995).

The otolith-based ${ }^{14} \mathrm{C}$ time series reconstruction reported here represents the most northerly such. reconstruction from calcified tissue yet reported. Yet the phase coherence between this time series and that reported elsewhere in the North Atlantic for bivalves (Weidman \& Jones 1993) and corals (Druffel 1989) is striking (Fig. 3). Pre-bomb ${ }^{14} \mathrm{C}$ activities for these taxa reflect a common baseline value, while differences in post-1970 activities probably reflect geographic variability in oceanic mixing times with deepwater sources (Weidman \& Jones 1993). However, the period of increasing ${ }^{14} \mathrm{C}$ activity (1958 to 1965 ) is virtually identical among the various regions and taxa. The presence of a strong phase coherence across such a broad array of organisms and areas has excellent implications for the age determination of other North Atlantic fish species. In all likelihood, it will not be possible to generate otolith-based ${ }^{14} \mathrm{C}$ reference curves for all species and stocks, due to the absence of historic collections of young otoliths through the most critical period (1958 to 1965). However, given a common period of increase in ${ }^{14} \mathrm{C}$, it should be possible to relate the ${ }^{14} \mathrm{C}$ time series reconstructed from the otolith cores of old fish to one of the other North Atlantic time series; errors in annulusbased age determinations would manifest themselves as non-coherent time series. This is essentially what Kalish $(1993,1995 a$, b) has done, albeit without a test of the coherence assumption. The only constraint to such an age determination procedure would be the requirement for fish hatched during the 1958 to 1965 period, so as to take advantage of the unique ${ }^{14} \mathrm{C}$ values during that period. However, since fish of any age from those yearclasses can be used in the analysis, the appropriate material is more likely to be available than would a collection of age 1 otoliths. 

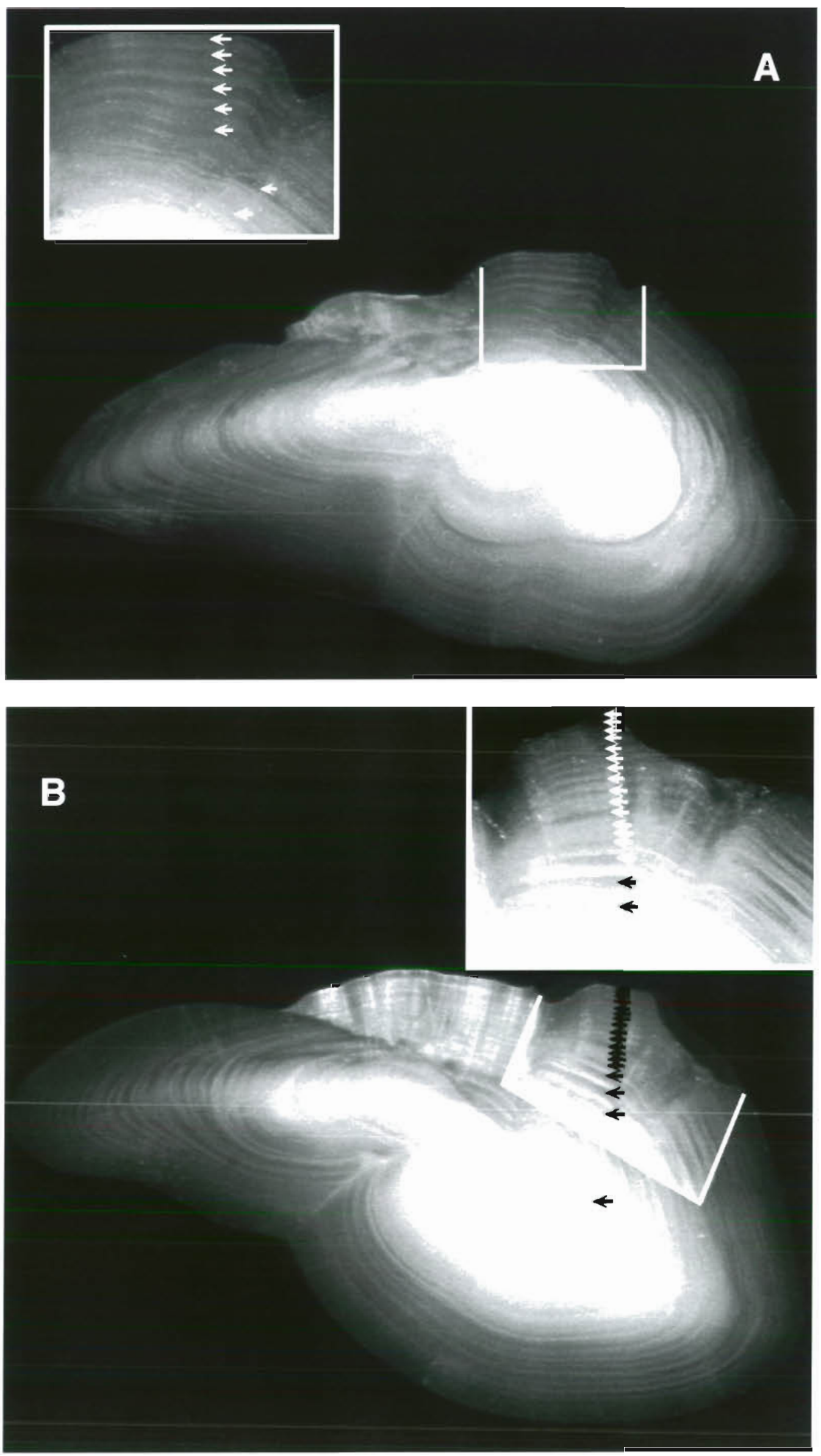


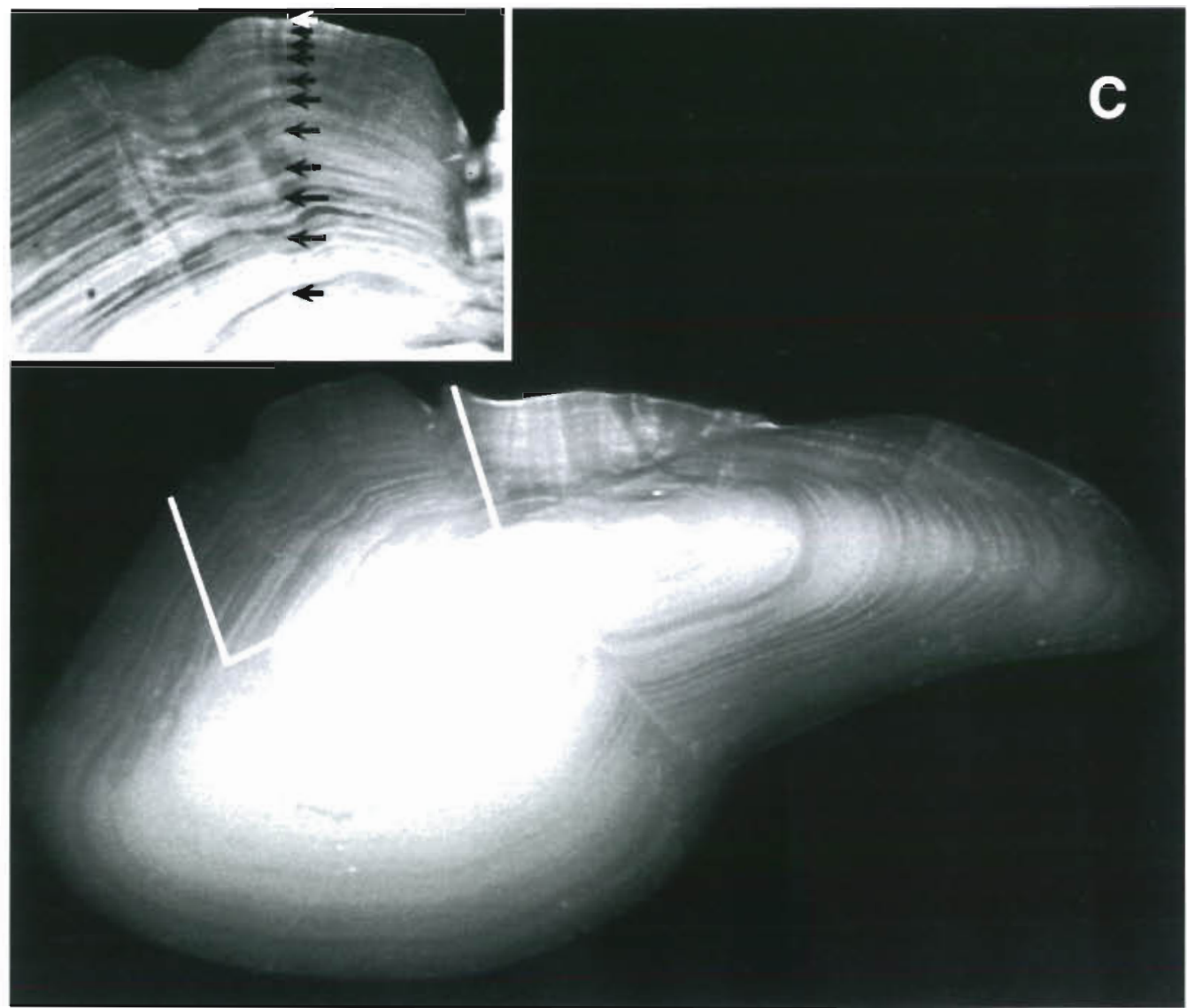

Fig. 2 (facing page and above). Transverse sections of 3 adult haddock otoliths for which corresponding $\Delta^{14} \mathrm{C}$-based ages were available. Annular ages were based on 3 sections per otolith; only 1 is shown here. Uncertainty in the $\Delta^{14} \mathrm{C}$ ages was 1 to 2 yr. Annuli (arrowed, except for edge) were most visible and provided the most reliable indication of age in the thickened region immediately beside the sulcus (shown in insert), although annulus count appeared to under-represent the $\Delta^{14} \mathrm{C}$-based age in some instances. Some sections of panels $(B)$ and $(C)$ have been digitally enhanced. (A) Annulus age $=8+; \Delta^{14} \mathrm{C}$ age $=10 ;(B)$ annulus age $=19 ; \Delta^{14} \mathrm{C}$ age $=22 ;(\mathrm{C})$ annulus age $=12 ; \Delta^{1+} \mathrm{C}$ age $=16$

While the ${ }^{14} \mathrm{C}$ assays reported here provided absolute age determinations for a number of old haddock, they were of greater value for their use in confirming the accuracy of the criteria generally used to interpret annuli in haddock otoliths. On the basis of a reference collection of 400 haddock otoliths circulated to 5 laboratories expert in ageing fishes, Campana (1995) reported that all 5 of the laboratories were consistent in their age interpretations, and all relied heavily on the region adjacent to and including the sulcus. This is the same region that provided the age interpretations most consistent with the ${ }^{14} \mathrm{C}$ ages in this study, although even this region resulted in minor underageing for fish $>13 \mathrm{yr}$ Thus the ageing criteria in use by these laboratories (and ours) for haddock appear to be largely correct, a finding which is unsurprising for fish $<8$ yr old, but one which has never been confirmed for very old haddock. Similar annulus criteria and axes of interpretation are also used by those studying the ages

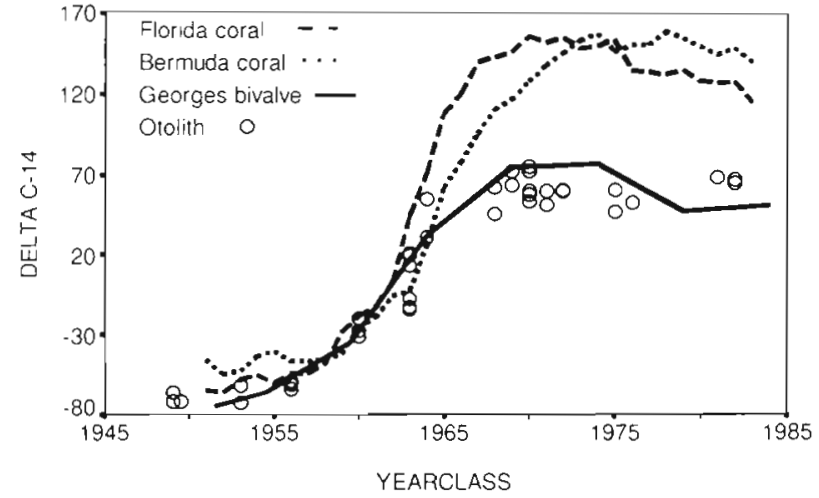

Fig. 3. $\triangle^{14} \mathrm{C}$ concentrations in the otoliths of young haddock in relation to published $\Delta^{14} \mathrm{C}$ chronologies for corals from Bermuda and Florida and a bivalve from Georges Bank. While the peak values for the corals differed from those of the haddock and the bivalve, the period of increasing values was virtually identical in all 4 time series. The 2 coral chronologies are drawn from Druffel (1989), while that for the bivalve is from Weidman \& Jones (1993) 
of other long-lived fish species (Chilton \& Beamish 1982, Penttila \& Dery 1988), underlining the significance of the region adjacent to the sulcus as the region of continued otolith growth in old fishes (Campana 1984).

While techniques such as the mark-recapture of chemically tagged fish can be used to validate the annual frequency of formation of growth increments in the otolith, only radiocarbon from nuclear fallout has the potential to both confirm annulus formation and absolute age in individual fish. The results of this study suggest that the absolute age of wild fish can be estimated with an accuracy of 1 to $2 \mathrm{yr}$, a result that cannot be matched by any other existing age validation technique. While the availability of suitable otolith samples may limit the applicability of this approach to specific stocks and species, use of fallout-derived radiocarbon as a dated otolith marker appears to provide the most accurate and logistically feasible method for age validation that is currently available.

Acknowledgements. I very much appreciate the technical assistance of Bruce Anderson, Peter Comeau and Joanne Hamel in preparing the otoliths, and the expertise of John Conrod in developing the otolith coring device. The ${ }^{14} \mathrm{C}$ assays were carned out under contract by Beta Analytic Inc John Kalish provided a helpful introduction to the approach. Chris Taggart and Clyde George alerted me to the existence of the archived otolith material. I particularly thank Peter Shelton and Harry Hicks of the Northwest Atlantic Fisheries Centre in St. John's, Newfoundland for providing access to the otolith archives for haddock.

\section{LITERATURE CITED}

Bada JL, Peterson RO, Schimmelmann A, Hedges REM (1990) Moose teeth as monitors of environmental isotopic parameters. Oecologia 82:102-106

Beamish RJ, McFarlane GA (1995) A discussion of the umportance of aging errors, and an application to walleye pollock: the world's largest fishery. In: Secor DH, Dean JM, Campana SE (eds) Recent developments in fish otolith research. University of South Carolina Press, Columbia, p 54.5-565

Beckman DW, Wilson CA (1995) Seasonal timing of opaque zone formation in fish otoliths. In: Secor DH, Dean JM, Campana SE (eds) Recent developments in tish otolith research. University of South Carolina Press, Columbia, p $27-43$

Bennett JT, Boehlert GW, Turekian KK (1982) Confirmation of longevity in Sebastes diploproa (Pisces: Scorpaenidae) from $\mathrm{Pb}-210 / \mathrm{Ra}-226$ measurements in otoliths. Mar Brol 71:209-215

Broecker WS, Peng TH, Ostlund G, Stuvier M (1985) The distribution of bomb radiocarbon in the ocean. J Geophys Res 90:6953-6970

This article was submitted to the editor
Campana SE (1984) Comparison of age determination methods for the starry flounder Trans Am Fish Soc 113: $365-369$

Campana $S$ (1995) Expert age determination of $4 \mathrm{VW}$ and $4 \mathrm{X}$ haddock otoliths by national and international laboratories. Dept of Fisheries and Oceans Atlantic Fisheries Research Document 95/120, Dartmouth, NS

Campana SE, Neilson JD (1985) Microstructure of fish otoliths. Can J Fish Aquat Sci 42:1014-1032

Campana SE, Zwanenburg KCT, Smith JN (1990) 210Pb/ 226Ra determination of longevity in redfish. Can J Fish Aquat SC1 47:163-165

Chilton DE, Beamish RJ (1982) Age determination methods for fishes studied by the Groundfish Program at the Pacific Biological Station. Can Spec Publ Fish Aquat Sci 60:1-102

Druffel EM (1989) Decadal time scale variability of ventilation in the North Atlantic: high-precision measurements of bomb radiocarbon in banded corals. J Geophys Res 94: $3271-3285$

Duffy PB, Eliason DE, Bourgeois AJ, Covey CC (1995) Simulation of bomb radiocarbon in two global ocean general circulation models. J Geophys Res 100:22545-22563

Foreman T (1996) Estimates of age and growth, and an assessment of ageing technıques, for northern bluefin tuna, Thunnus thynnus, in the Pacific Occan. Inter-Am Trop Tuna Comm Bull 21:1-105

Kalish JM (1993) Pre- and post-bomb radiocarbon in fish otoliths. Earth Planet Sci Lett 114:549-554

Kalish JM (1995a) Application of the bomb radiocarbon chronometer to the validation of redfish Centroberyx affjnis age. Can J Fish Aquat Sci 52:1399-1405

Kalish JM (1995b) Radiocarbon and fish biology. In: Secor DH, Dean JM, Campana SE (eds) Recent developments in fish otolith research. University of South Carolina Press, Columbia, p $637-653$

Nydal R, Lovseth K (1983) Tracing bomb C-14 in the atmosphere 1962-1980. J Geophys Res 88:3621-3642

Peck LS, Brey T (1996) Bomb signals in old Antarctic brachiopods. Nature 380:207-208

Penttila J, Dery LM (1988) Age determination methods for Northwest Atlantic species. NOAA Tech Rep NMFS 72 : $1-135$

Secor DH, Dean JM, Campana SE (eds) (1995) Recent developments in fish otolith research. University of South Carolina Press, Columbia

Strong M, Hunt JJ, Robicheau RK (1985) A new method of preparing gadoid otoliths. Canadian Atlantic Fisheries Scientific Advisory Committee Research Document 85/70, Dartmouth, NS

Stuiver Mi Polach HA (1977) Reporting of C-14 data. Radiocarbon 19:355-363

Turekian KK, Cochran JK, Nozaki Y (1982) Determination of shell deposition rates of Arctica islandica from the New York Bight using natural Ra-228 and Th-228 and bombproduced C-14. Limnol Oceanogr 27:737-741

Weidman CR, Jones GA (1993) A shell-derived time history of bomb $\mathrm{C}-14$ on Georges Bank and its Labrador Sea implications. J Geophys Res 98:14577-14588

Zwanenburg KCT, Bentzen. P, Wright JM (1992) Mitochondrial DNA differentiatjon in western North Atlantic populations of haddock (Melanogrammus aeglefinus). Can J Fish Aquat Sci 49:2527-2537

Manuscript furst received: December 9, 1996 Revised version accepted: February 10,1997 